\title{
Aplikasi Pendiagnosa Penyakit Mata Dengan Menggunakan Metode Certainty Factor
}

\author{
Muhammad Yasin Simargolang ${ }^{1}$, Sri Rahmawati \\ Program Studi Teknik Informatika Universitas Asahan (UNA) \\ Jln. Ahmad Yani, Kisaran-21224 \\ muhammadyasins@gmail. $\mathrm{com}^{1}$, sri.rahma678@gmail. $\mathrm{com}^{2}$
}

\begin{abstract}
Abstrak - Pada zaman teknologi informasi saat ini, kebutuhan akan informasi yang lebih cepat dan mutakhir sangatlah dibutuhkan, mengingat informasi sudah menjadi sumber daya yang sangat penting bagi organisasi yang membutuhkan penanganan khusus seperti sumber daya lainnya. Mata merupakan anggota tubuh yang perlu dijaga dalam kesehatan sehari-hari. Seiring perkembangan teknologi yang sangat pesat, pada bidang kedokteran saat ini juga telah memanfaatkan teknologi untuk membantu peningkatan pelayanan yang lebih baik kepada masyarakat luas. Metode Certainty Factor digunakan agar mampu melakukan diagnosis dengan cepat, tepat dan akurat terhadap gejala penyakit yang ditimbulkan dan metode ini diharapkan mampu membantu para pasien terutama penyakit mata, tanpa terlebih dahulu ke rumah sakit. Metode ini memudahkan pengguna dalam memberikan jawaban terkait dengan besarnya kepercayaan terhadap gejala yang dialami.
\end{abstract}

Kata Kunci - Teknologi, Informasi, Mata, Metode Certainty Factor.

\section{PENDAHULUAN}

Pada zaman teknologi informasi saat ini, kebutuhan akan informasi yang lebih cepat dan mutakhir sangatlah dibutuhkan, mengingat informasi sudah menjadi sumber daya yang sangat penting bagi organisasi yang membutuhkan penanganan khusus seperti sumber daya lainnya. Informasi tidak hanya dibutuhkan oleh organisasi non-komersil dan juga pribadi, karena informasi merupakan sumber daya yang strategis dalam menetapkan berbagai kebijakan bagi semua pihak yang terkait di dalam organisasi, terutama bagi pimpinan organisasi.[1]

Seperti yang diketahui mata adalah suatu panca indra yang sangat penting dalam kehidupan manusia untuk melihat. Dengan mata melihat, manusia dapat menikmati keindahan alam dan berinteraksi dengan lingkungan sekitar dengan baik. Jika mengalami gangguan atau penyakit mata, maka akan berakibat sangat fatal bagi kehidupan manusia. Jadi sudah semestinya mata merupakan anggota tubuh yang perlu dijaga dalam kesehatan sehari-hari. Seiring perkembangan teknologi yang sangat pesat, pada bidang kedokteran saat ini juga telah memanfaatkan teknologi untuk membantu peningkatan pelayanan yang lebih baik kepada masyarakat luas. [2]

Metode Certainly Factor telah digunakan dalam beberapa contoh kasus diantaranya: untuk menentukan $\mathrm{CF}$ pengguna, telah dapat diimplementasikan dengan baik dalam aplikasi sistem pakar untuk menangani penyakit. Metode ini memudahkan pengguna dalam memberikan jawaban terkait dengan besarnya kepercayaan terhadap gejala yang dialami. [3]

Metode Certainly Factor digunakan agar mampu melakukan diagnosis dengan cepat, tepat dan akurat terhadap gejala penyakit yang ditimbulkan dan metode ini diharapkan mampu membantu para pasien terutama penyakit mata, tanpa terlebih dahulu ke rumah sakit.[4]

\section{LANDASAN TEORI}

\section{A. Pengertian Kecerdasan Buatan}

Menurut Edi Wijaya (2013) Kecerdasan buatan merupakan salah satu bagian ilmu komputer yang membuat agar mesin (komputer) dapat melakukan pekerjaan seperti dan sebaik yang dilakukan oleh manusia. Pada awal diciptakannya, komputer hanya difungsikan sebagai alat hitung saja. Namun seiring dengan perkembangan zaman, maka peranan komputer semakin mendominasi kehidupan umat manusia. Komputer tidak lagi hanya digunakan sebagai alat hitung, lebih dari itu komputer diharapkan dapat diberdayakan untuk mengerjakan segala sesuatu yang bisa dikerjakan manusia.

\section{B. Pengertian Sistem Pakar}

Menurut Yasidah Nur Istiqomah dan Abdul Fadlil (2013) Sistem pakar (Expert System) adalah sistem yang berusaha mengadopsi pengetahuan manusia ke komputer, agar komputer dapat menyelesaikan masalah seperti yang biasa dilakukan oleh para ahli. Dengan sistem pakar ini, orang awam pun dapat menyelesaikan masalah yang cukup rumit yang sebenarnya hanya dapat diselesaikan dengan bantuan para ahli.

\section{Penyakit Mata}

Menurut Reppy Reisa, dkk (2013) jenis-jenis penyakit mata adalah sebagai berikut:

1. Katarak

Katarak merupakan suatu keadaan di mana lensa mata yang biasanya jernih dan bening menjadi keruh. Faktor penyebab dan proses terjadinya katarak:

a. Katarak juvenile: katarak yang terlihat pada usia di atas 1 tahun dan di bawah 50 tahun. Merupakan lanjutan dari katarak congenital yang makin nyata.

b. Katarak kongenital: katarak yang terlihat pada usia di bawah 1 tahun/ Kekeruhan lensa yang didapatkan sejak lahir. 
c. Katarak Senilis: katarak yang dialami orang berusia lanjut atau di atas 50 tahun karena faktor degenerasi.

\section{Glaukoma}

Penjelasan tentang jenis penyakit mata

Glaukoma, sebagai berikut:

a. Glukoma Primer Sudut Terbuka

Biasanya terjadi pada penderita usia lanjut. Jaringan trabekula sebagai saluran keluar akan tersumbat dan menyebabkan tekanan dalam bola mata meningkat secara perlahan. Peningkatan tekanan secara perlahan ini menyebabkan kerusakan saraf mata secara perlahan pula, maka penderita penyakit ini disebut Glaukoma Primer Sudut Terbuka. Jenis glaukoma ini akan merusak tajam penglihatan secara perlahan-lahan dan tanpa rasa sakit, sehingga penderita tidak menyadari keadaan matanya dan akhirnya terjadi kebutaan atau kerusakan saraf mata yang sudah tidak dapat ditolong lagi.

b. Glaukoma Primer Sudut Tertutup

Jenis glaukoma ini adalah jenis yang terbanyak terjadi di Indonesia. Sudut bilik mata depan akan tertutup secara mendadak dan menyumbat aliran cairan bola mata. Akibatnya tekanan dalam bola mata mendadak naik tinggi dan menyebabkan berbagai gejala klinis. Bila tidak diobati segera, maka glaukoma ini akan menyebabkan kebutaan.

\section{Mata Juling}

Strabismus (Mata juling) adalah suatu keadaan yang ditandai dengan penyimpangan abnormal dari letak satu mata terhadap mata yang lainnya, sehingga garis penglihatan tidak paralel dan pada waktu yang sama, kedua mata tidak tertuju pada benda yang sama. Penyakit mata juling biasanya dialami oleh anak-anak yang berusia 1-3 tahun. Beberapa jenis strabismus:

a. Esotropia : mata melenceng ke arah dalam.

b. Eksotropia : mata melenceng ke arah luar.

c. Hipertropia : mata melenceng ke arah atas.

d. Hipotropia : mata melenceng ke arah bawah.

\section{Timbilen (Hordeolum)}

Timbilen atau timbil yang dalam bahasa medis disebut Hordeolum. Penyakit ini dapat menyerang siapa saja, mulai anak-anak hingga orang tua. Disebutkan bahwa angka kejadian pada usia dewasa lebih banyak dibanding anak anak.Penyebaran kuman tersebut antara lain melalui udara. Ada dua jenis timbilen, yang pertama hordeolum externum, benjolannya terlihat di luar kelopak mata, yang kedua, hordeolum internum yang hanya berupa benjolan yang berada di dalam kelopak mata.

\section{Daging Tumbuh ( Pterygium)}

Pterygium adalah munculnya suatu timbunan atau selaput pada mata yang bentuknya seperti segitiga dengan puncak berada di arah kornea mata. Pterygium oleh sebagian orang dikenal sebagai "daging tumbuh" di selaput bening mata. Penyebab pterygium diduga karena faktor iritasi dari luar seperti: sinar matahari, panas, debu dan angin. Karena itu untuk mencegah timbulnya pterygium dapat dilakukan dengan cara menghindari paparan sinar matahari (ultraviolet) dengan memakai kacamata hitam, topi atau payung.

\section{Faktor Kepastian (Certainty Faktor)}

Menurut Wesley dalam Hengki Tamando Sihotang (2014) Faktor kepastian (certainty factor) diperkenalkan oleh Shortliffe Buchanan dalam pembuatan MYCIN (Wesley, 1984). Certainty factor (CF) merupakan nilai parameter klinis yang diberikan MYCIN untuk menunjukkan besarnya kepercayaan. Dalam menghadapi suatu masalah sering ditemukan jawaban yang tidak memiliki kepastian penuh. Ketidakpastian ini bisa berupa probabilitas atau kebolehjadian yang tergantung dari hasil suatu kejadian. Hasil yang tidak pasti disebabkan oleh dua faktor yaitu aturan yang tidak pasti dan jawaban pengguna yang tidak pasti atas suatu pertanyaan yang diajukan oleh sistem. Hal ini sangat mudah dilihat pada system diagnosis penyakit, dimana pakar tidak dapat mendefinisikan tentang hubungan antara gejala dengan penyebabnya secara pasti, dan pasien tidak dapat merasakan suatu gejala dengan pasti pula. Pada akhirnya ditemukan banyak kemungkinan diagnosis. Faktor kepastian (certainty factor) diperkenalkan oleh Shortliffe Buchanan dalam pembuatan MYCIN (Wesley, 1984). Certainly factor (CF) merupakan nilai parameter klinis yang diberikan MYCIN untuk menunjukkan besarnya kepercayaan. Certainty factor didefinisikan sebagai berikut (Giarattano dan Riley, 1994):

\section{$\mathrm{CF}(\mathrm{H}, \mathrm{E})=\mathrm{MB}(\mathrm{H}, \mathrm{E})-\mathrm{MD}(\mathrm{H}, \mathrm{E})$}

$\mathrm{CF}(\mathrm{H}, \mathrm{E})$ : certainty factor dari hipotesis $\mathrm{H}$ yang dipengaruhi oleh gejala (evidence) E. Besarnya $\mathrm{CF}$ berkisar antara -1 sampai dengan 1. Nilai -1 menunjukkan ketidakpercayaan mutlak sedangkan nilai 1 menunjukkan kerpercayaan mutlak.

$\mathrm{MB}(\mathrm{H}, \mathrm{E})$ : ukuran kenaikan kepercayaan (measure of increased belief) terhadap hipotesis $\mathrm{H}$ yang dipengaruhi oleh gejala E.

$\mathrm{MD}(\mathrm{H}, \mathrm{E})$ : ukuran

kenaikan ketidakpercayaan (measure of increased disbelief) terhadap hipotesis $\mathrm{H}$ yang dipengaruhi oleh gejala $\mathrm{E}$.

Sistem pakar ini terdiri dari beberapa kaidah yang berupa fakta dan aturan untuk menghasilkan keputusan (Adhi Sadewo : 2010). Formula CF untuk beberapa kaidah yang mengarah pada hipotesa yang sama dapat dituliskan sebagai berikut

$$
\mathrm{CF}(\mathrm{H})\left\{\begin{array}{l}
\mathrm{CF}(\mathrm{R} 1)+\mathrm{CF}(\mathrm{R} 2)-[\mathrm{CF}(\mathrm{R} 1) \\
\mathrm{CF}(\mathrm{R} 2)] \text {; nilai } \mathrm{CF}(\mathrm{R} 1) \text { dan } \mathrm{CF}(\mathrm{R} 2)> \\
0 \\
\mathrm{CF}(\mathrm{R} 1)+\mathrm{CF}(\mathrm{R} 2)+[\mathrm{CF}(\mathrm{R} 1) * \\
\mathrm{CF}(\mathrm{R} 2)] \text {; nilai } \mathrm{CF}(\mathrm{R} 1) \text { dan } \mathrm{CF}(\mathrm{R} 2)<
\end{array}\right.
$$




$\begin{array}{ll}C F(R 1)+C F(R 2) ; & \\ \text { nilai } \mathrm{CF}(\mathrm{R} 1) & \text { dan } \mathrm{CF}(\mathrm{R} 2) \\ \text { berlawanan } & \text { tanda1-min[|CF } \\ (R 1)|,| C F(R 2) \mid] & \end{array}$

Pada implementasi sistem pakar diagnosa penyakit paru-paru dan saluran pernafasan ini, nilai $\mathrm{CF}$ per aturan berada pada kisaran 0.1 sampai dengan 1 . Hal ini berarti nilai $\mathrm{CF}>0$, sehingga akan menggunakan rumus :

$\mathrm{CF}(\mathrm{R} 1, \mathrm{R} 2)=\mathrm{CF}(\mathrm{R} 1)+\mathrm{CF}(\mathrm{R} 2)-[(\mathrm{CF}(\mathrm{R} 1) \mathrm{x}$ $\mathrm{CF}(\mathrm{R} 2)] \ldots(1)$

Karena nilai CF yang diberikan bernilai positif. Rumus tersebut kemudian dapat diterapkan pada beberapa rule yang berbeda secara bertingkat. Nilai CF setiap premis/gejala merupakan nilai yang diberikan oleh seorang pakar didasarkan pada ilmu pengetahuan dan pengalaman yang dimilikinya.Diasumsikan ada dua aturan (Fahmi Rahmadi, 2009) :

$\mathrm{R} 1$ : IF harga diturunkan $(\mathrm{CF}=0,3)$ THEN keuntungan meningkat

$\mathrm{R} 2$ : IF diberikan diskon $(\mathrm{CF}=0,4)$ THEN keuntungan meningkat

Perhitungan kombinasinya :

$$
\begin{array}{ll}
\mathrm{CF}(\mathrm{R} 1, \mathrm{R} 2)= & \mathrm{CF}(\mathrm{R} 1)+\mathrm{CF}(\mathrm{R} 2) \times[1-\mathrm{CF}(\mathrm{R} 1)] \\
& =\mathrm{CF}(\mathrm{R} 1)+\mathrm{CF}(\mathrm{R} 2)-[\mathrm{CF}(\mathrm{R} 1) \mathrm{x} \\
& \mathrm{CF}(\mathrm{R} 2)] \\
\mathrm{CF}(\mathrm{R} 1) & =0,3 \mathrm{DAN} \mathrm{CF}(\mathrm{R} 2)=0,4 \text { maka } \\
\mathrm{CF}(\mathrm{R} 1, \mathrm{R} 2) & =0,3+0,4-(0,3)(0,4)=0,58
\end{array}
$$

Sistem pakar harus mampu bekerja dalam ketidakpastian. Sejumlah teori telah ditemukan untuk menyelesaikan ketidakpastian,termasuk diantaranya probabilitas klasik (classical probability), probabilitas Bayes (Bayesian probability), teori Hartley berdasarkan himpunan klasik (Hartley theory based on classical sets), teori Shannon berdasarkan pada probabilitas (Shannon theory based on probability), teori Dempster-Shafer (Dempster-Shafer theory), teori fuzzy Zadeh (Zadeh.s fuzzy theory) dan faktor kepastian (certainty factor). Dalam penelitian ini yang digunakan adalah faktor kepastian.

Adapun Faktor kepastian merupakan suatu metode yang digunakan untuk mengukur suatu keyakinan seseorang, inputnya adalah berupa kepastian dari pakar.

a. Probabilitas Dan Certainly Factor

Certainty factor didefenisikan sebagai persamaan berikut : $\mathrm{CF}(\mathrm{H}, \mathrm{E})=\mathrm{MB}(\mathrm{H}, \mathrm{E})-\mathrm{MD}(\mathrm{H}, \mathrm{E}) \mathrm{CF}$ $(\mathrm{H}, \mathrm{E})$ : certainly factor dari hipotesis $\mathrm{H}$ yang dipengaruhi oleh gejala (evidence) E. Besarnya $\mathrm{CF}$ berkisar antara -1 sampai 1. Nilai -1 menunjukkan ketidakpercayaan mutlak sedangkan nilai 1 menunjukkan kepercayaan mutlak $\mathrm{MB}(\mathrm{H}$, E) : ukuran kenaikan kepercyaan (measure of increased belief) terhadap hipotesis $\mathrm{H}$ yang dipengaruhi oleh gejala $\mathrm{E} . \mathrm{MD}(\mathrm{H}, \mathrm{E})$ : ukuran kenaikan ketidakpercayaan (measure of increased disbelief) terhadap hipotesis $\mathrm{H}$ yang dipengaruhi oleh gejala E. Bentuk dasar rumus certainly factor, adalah sebuah aturan jika $\mathrm{E}$ maka $\mathrm{H}$ seperti ditunjukkan oleh persamaan berikut : $\mathrm{CF}(\mathrm{H}, \mathrm{e})=$ $\mathrm{CF}(\mathrm{E}, \mathrm{e}) * \mathrm{CF}(\mathrm{H}, \mathrm{E})$ Dimana : $\mathrm{CF}(\mathrm{H}, \mathrm{E})$ : certainly Factor hipotesis yang dipengaruhi oleh evidence e. $\mathrm{CF}(\mathrm{E}, \mathrm{e})$ : Certainly Factor evidence E yang dipengaruhi oleh evidence e. $\mathrm{CF}(\mathrm{H}, \mathrm{E})$ : Certainly Factor hipotesis dengan asumsi evidence diketahui dengan pasti, yaitu ketika $\mathrm{CF}$ $(\mathrm{E}, \mathrm{e})=1$. Jika Evidence pada antecedent diketahui dengan pasti maka persamaannya akan menjadi : $\mathrm{CF}(\mathrm{E}, \mathrm{e})=\mathrm{CF}(\mathrm{H}, \mathrm{E})$. Nilai $\mathrm{CF}$ (rule) didapat dari interpretasi "term" dari pakar, yang

\begin{tabular}{|c|c|}
\hline Uncertain Term & $\mathrm{CF}$ \\
\hline Pasti tidak & -1.0 \\
\hline Hampir pasti tidak & -0.8 \\
\hline Kemungkinan besar tidak & -0.6 \\
\hline Mungkin tidak & -0.4 \\
\hline Tidak tahu & -0.2 to 0.2 \\
\hline Mungkin & 0.4 \\
\hline Kemungkinan besar & 0.6 \\
\hline Hampir pasti & 0.8 \\
\hline Pasti & 1.0 \\
\hline
\end{tabular}
diubah menjadi nilai $\mathrm{CF}$ tertentu sesuai tabel berikut:

TABEL 1

Nilai Certainly Faktor

b. Perhitungan Certainly Factor Gabungan

Secara umum, rule direpresentasikan dalam bentuk sebagai berikut : IF E1 AND E2...... AND En THEN H (CF rule) Atau IF E1 OR E2........ OR En THEN H (CF rule). Dimana : E1... En : fakta - fakta (evidence) yang ada $\mathrm{H}$ : Hipotesis atau konklusi yang dihasilkan $\mathrm{CF}$ rule : Tingkat keyakinan terjadinya hipotesis $\mathrm{H}$ akibat adanya fakta - fakta E1.... En.

c. Kelebihan dan Kekurangan Metode Certainty Factor

Kelebihan metode certainty factor adalah :

1. Metode ini cocok dipakai dalam system pakar yang mengandung ketidakpastian.

2. Dalam sekali proses perhitungan hanya dapat mengolah 2 data saja sehingga keakuratan data dapat terjaga.

Sedangkan kekurangan metode certainly factor adalah :

1. Pemodelan ketidakpastian yang menggunakan perhitungan metode certainly factor biasanya masih diperdebatkan.

2. Untuk data lebih dari 2 buah, harus dilakukan beberapa kali pengolahan data.

E. Pemodelan Unified Modelling Language (UML) Menurut Helmi Fauzi Siregar dan Gellysa Urva (2015) UML (Unified Modeling Language) merupakan metodologi dalam mengembangkan sistem 
berorientasi objek dan juga merupakan alat untuk mendukung pengembangan sistem.

Menurut Pratama (2014:48) Unified Modelling Language (UML) adalah standarisasi bahasa pemodelan untuk membangun perangkat lunak yang dibangun dengan menggunakan teknik pemrograman berorientasi objek Pada umumnya hanya digunakan empat buah diagram saja dalam sebuah UML, yaitu Use Case Diagram, Class Diagram, Activity Diagram dan Sequence Diagram.

\section{Use Case Diagram}

Use Case diagram menggambarkan aliran kegiatan dan proses bisnis yang dilakukan oleh pengguna (aktor). Pada diagram Use Case ini, setiap kegiatan digambarkan ke dalam sebuah Use Case berbentuk lonjong dan terdapat minimal seorang aktor.

\section{Class Diagram}

Class diagram menggambarkan stuktur sistem dari segi pendefinisian kelas-kelas yang akan dibuat untuk membangun sistem. Kelas memiliki apa yang disebut atribut dan metode atau operasi.

\section{Activity Diagram}

Activity diagram menggambarkan workflow (aliran kerja) dari sebuah sistem atau proses bisnis atau menu yang ada pada perangkat lunak.

\section{Sequence Diagram}

Sequence diagram menggambarkan kelakukan objek pada use case dengan mendeskripsikan waktu hidup objek dan pesan yang dikirimkan dan diterima antar objek.

\section{F. Basis Data}

Menurut Supartini dan Hindarto (2016), Basis data atau database merupakan kumpulan data yang disimpan secara sistematik di dalam komputer, dimana basis data juga dapat diolah atau dimanipulasi menggunakan perangkat lunak atau program aplikasi untuk menghasilkan informasi. Pendefinisian basis data meliputi spesifikasi berupa tipe data, struktur data dan batasan-batasan yang akan disimpan.

Berikut ini adalah tahapan perancangan database adalah sebagai berikut:

1. Pengumpulan data dan analisis.

2. Perancangan database secara konseptual

3. Pemilihan Database Management System.

4. Perancangan database secara logika (data model mapping).

5. Perancangan database secara fisik.

6. Implementasi sistem database.

\section{G. Perl Hypertext Preprocessor (PHP)}

Menurut Helmi Fauzi Siregar dan Gellysa Urva (2015) PHP merupakan bahasa scripting yang berjalan disisi server (server-slide). Semua perintah yang dieksekusi oleh server dan hasilnya dapat dilihat melalui browser.
Menurut Dzulkifli Fitriana, dkk (2016) menjelaskan bahwa "XAMPP adalah perangkat lunak bebas, yang mendukung banyak sistem operasi, merupakan kompilasi dari beberapa program. Fungsinya adalah sebagai server yang berdiri sendiri (localhost), yang terdiri atas program Apache HTTP Server, MySQL database, dan penerjemah bahasa yang ditulis dengan bahasa pemrograman PHP dan Perl. Nama XAMPP merupakan singkatan dari X (empat sistem operasi apapun), Apache, MySQL, PHP dan Perl. Program ini tersedia dalam GNU General Public License dan bebas, merupakan web server yang mudah digunakan yang dapat melayani tampilan halaman web yang dinamis.

\section{HTML (Hyper Text Markup Language)}

Menurut Eka Wida Fridayanthie dan Tias Mahdiati (2016), Hyper Text Markup Language atau HTML adalah bahasa standar yang digunakan untuk menampilkan halaman web. Yang bisa dilakukan dengan HTML yaitu: mengatur tampilan dari halaman web dan isinya, membuat table dalam halaman web, mempublikasikan halaman web secara online, membuat form yang bisa digunakan untuk menangani registrasi dan transaksi via web, menambahkan objekobjek seperti citra, audio, video, animasi, java aplet dalam halaman web, serta menampilkan area gambar (canvas) di browser.

\section{J. $\quad M y S Q L$}

Menurut Eka Wida Fridayanthie dan Tias Mahdiati (2016) "MySQL (My Structure Query Languange) adalah salah satu jenis database server yang sangat terkenal dan banyak digunakan untuk membangun aplikasi web yang menggunakan database sebagai sumber dan pengelolaan datanya". MySQL bersifat open source dan menggunakan SQL (Structured Query Languange). MySQL biasa dijalankan diberbagai platform misalnya windows Linux, dan lain sebagainya.

\section{A. Rancangan Penelitian}

\section{METODOLOGI PENELITIAN}

Untuk menyusun tugas akhir ini, adapun dilakukan penerapan rancangan penelitian dalam memperoleh data-data yang dibutuhkan sehingga penyusun dalam penelitian ini dapat di selesaikan dengan baik dan sistematis. Dalam rancangan penelitian yang penulis buat terdiri dari studi pustaka, analisis, desain, implementasi dan evaluasi. Untuk lebih jelasnya, kerangka rancangan penelitian dapat dilihat pada gambar 1 .

\section{H. XAMPP}




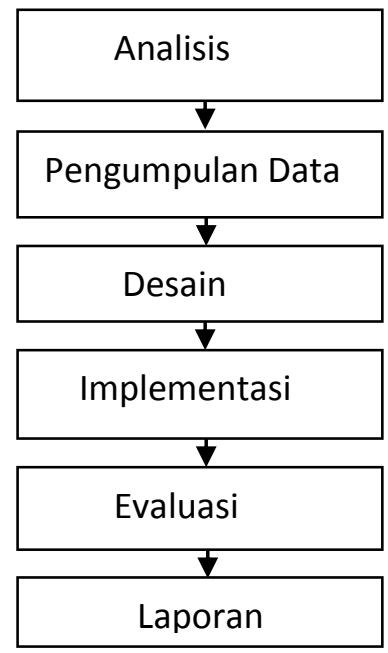

Gambar 1. Rancangan Penelitian

\section{ANALISIS DAN IMPLEMENTASI}

\section{A. Analisa Sistem Pakar Penyakit Mata}

Di dalam analisis kebutuhan sistem, data yang berhubungan denganinformasi penyakit mata didapat dari wawancara dengan pakar dalam hal inidokter spesialis mata, internet, buku dan literatur lainnya. Data yang telahterkumpul akan diidentifikasikan untuk keperluan pembuatan sistem pakar. Hasildari analisa sistem adalah penilaian keadaan, akuisisi pengetahuan,representasi pengetahuan dan analisa menggunakan metode certainty factor.

\section{B. Analisis Kebutuhan}

Sebelum membangun sebuah perangkat lunak sistem pakar penyakit mata terlebih dahulu harus ada analisa yang baik, hal ini dimaksudkan agar pembuatansistem pakar penyakit mata tersebut jelas sesuai dengan tujuan yang ingin disampaikan. Ada beberapa hal yang berkaitan dalam membangun sebuah sistem pakar penyakit mata, yaitu analisis kebutuhan dan juga spesifikasi perangkat lunak yang dibutuhkan meliputi :

1. Perangkat lunak sistem pakar penyakit mata ini menyediakan informasi tentang penyakit mata dan dapat mendiagnosa penyakit mata berdasarkan gejala yang dipilih pengguna.

2. User atau pengguna sistem pakar ini secara umum dibagi menjadi dua, yaitu: pengguna dan pakar.

a. Pengguna merupakan pemakai yang terlebih dahulu menjadi anggota dari sistem ini. Setelah tercatat sebagai anggota maka dapat melakukan konsultasi.

b. Pakar merupakan user yang bisa mengakses sistem keseluruhan, dimulai dari memasukkan data akuisisi pengetahuan dan juga menerima keluhan atau usulan dari pengguna.

3. Aktifitas yang akan dijumpai di dalam sistem pakar penyakit mata ini adalah pengguna dapat mengetahui informasi jenis penyakit mata, gejala penyakit mata dengan besar probabilitasnya, pengobatan dan usulan dengan pakar serta memberikan fasilitas berupa menu pakar yang memungkinkan pakar mengolah data (merubah, menambah, menghapus) penyakit, penyebab, gejala, nilai probabilitas dan solusi.

4. Target yang akan dicapai dari sistem pakar penyakit mata adalah pengguna dapat mengetahui penyakit mata yang sedang dideritadengan memilih gejala yang di sediakan sistem sehingga pengguna mendapatkan informasi secara cepat, akurat dan kapan saja tentang jenis penyakit mata beserta besar probabilitasnya, gejala penyakit mata, keterangan pengobatan secara dini.

\section{Perhitungan Nilai Certainty Factor}

Jika user memilih 5 gejala penyakit dari daftar pertanyaan yang telah disediakan oleh sistem seperti dibawah ini :

$\begin{array}{ll}\text { If } & \text { Mata merah } \\ \text { And } & \text { Gatal } \\ \text { And } & \text { Epifora } \\ \text { And } & \text { Eksudat } \\ \text { And } & \text { Rasa terbakar pada palpebra } \\ \text { Then } & \text { Blefaritis }\end{array}$

Maka sistem akan menghitung nilai MB dan MD yang ada pada tabel basis pengetahuan, berikut contoh perhitungan manual:

Penyakit Blefaritis

Gejala 1 (G001) Mata merah 0.15

\begin{tabular}{|c|c|c|}
\hline MB Lama & Kosong & \\
\hline $\begin{array}{r}\text { MD Lama } \\
0\end{array}$ & & Kosong \\
\hline $\begin{array}{r}\text { MB Baru } \\
0.9\end{array}$ & & $\mathrm{MB}$ \\
\hline $\begin{array}{l}\text { MD Baru } \\
0.15\end{array}$ & & MD \\
\hline $\begin{array}{c}\text { MB Sementara } \\
0.9\end{array}$ & MB Baru & \\
\hline $\begin{array}{c}\text { MD Sementara } \\
0.15\end{array}$ & MD Baru & \\
\hline $\begin{array}{c}\text { Gejala } 2 \text { (G002) } \\
0.2\end{array}$ & Gatal & 0.9 \\
\hline $\begin{array}{r}\text { MB Lama } \\
0.9\end{array}$ & & MB Sementara \\
\hline $\begin{array}{l}\text { MD Lama } \\
0.15\end{array}$ & & MD Sementara \\
\hline $\begin{array}{r}\text { MB Baru } \\
0.9\end{array}$ & & MB \\
\hline MD Baru & & $\mathrm{MD}$ \\
\hline
\end{tabular}

MB Sementara MB Lama + (MB Baru * (1 - MD
Lama))
$0.9+(0.9 *(1-0.9)$

0.99 


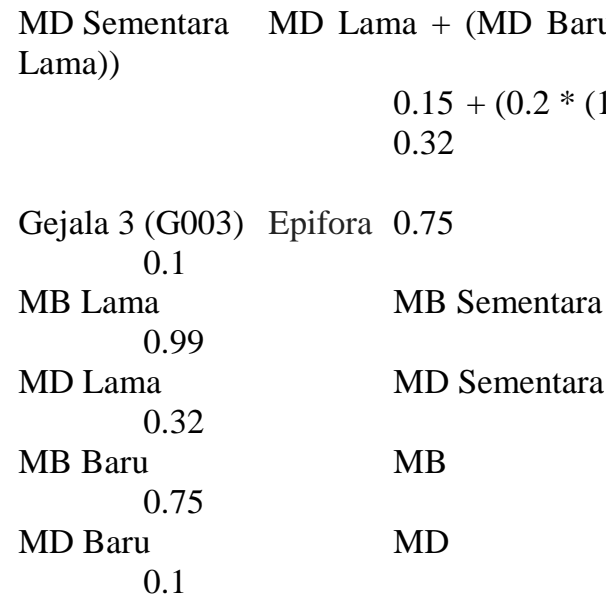

MB Sementara Lama))

$\mathrm{MB} \mathrm{Lama}+(\mathrm{MB}$ Baru * $(1-\mathrm{MD}$ $0.99+(0.75 *(1-0.99)$ 0.9975

MD Sementara

Lama))

$\mathrm{MD} \mathrm{Lama} \mathrm{+} \mathrm{(MD} \mathrm{Baru} \mathrm{*}(1-\mathrm{MD}$

$0.32+(0.1 *(1-0.32)$

0.388

Gejala 4 (G004) Eksudat 0.85

$$
0.2 \mathrm{MB} \text { Lama }
$$$$
0.9975
$$

$\begin{array}{lll}\text { MD Lama } & \text { MD Sementara } & 0.388 \\ \text { MB Baru } & \text { MB } & 0.85 \\ \text { MD Baru } & \text { MD } & 0.2 \\ \text { MB Sementara } & \text { MB Lama + (MB Baru } *(1-\text { MD } \\ \text { Lama }) & 0.9975+(0.85 *(1-0.9975) \\ & 0.999625 \\ \text { MD Sementara } & \text { MD Lama + (MD Baru * }(1-\text { MD } \\ \text { Lama) }) & 0.388+(0.2 *(1-0.388) \\ & 0.5104\end{array}$

Gejala 5 (G005) Rasa terbakar pada palpebra 0.8 0.1

$\begin{array}{llc}\text { MB Lama } & \text { MB Sementara } & 0.9996 \\ \text { MD Lama } & \text { MD Sementara } & 0.5104 \\ \text { MB Baru } & \text { MB } & 0.8 \\ \text { MD Baru } & \text { MD } & 0.1 \\ \text { MB Sementara } & \text { MB Lama + (MB Baru * }(1-\text { M } \\ \text { Lama) } & \\ & 0.999625+(0.8 *(1-0.999625) \\ \text { MD Sementara } & \text { MD Lama + (MD Baru * }(1- \\ \text { Lama)) } & 0.5104+(0.1 *(1-0.5104) \\ & 0.55936 \\ & \\ \text { Nilai CF } & \text { MB Sementara - MD Sementara } \\ & 0.999925-0.55936 \\ & 0.440565\end{array}$

Penyakit Keratitis

Gejala 1 (G001) Mata merah 0.2

MB Lama a

Kosong

Kosong
MB Baru

0.6

MD Baru

0.2

MB Sementara MB Baru 0.6

MD Sementara MD Baru 0.2

Nilai CF MB Sementara - MD Sementara
$0.6-0.2$
0.4

Penyakit Konjungtivitis Sika

Gejala 2 (G002) Gatal 0.5 0.15

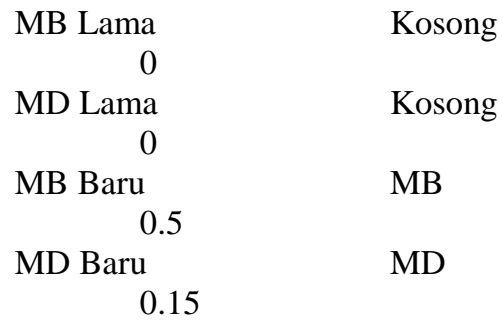

MB Sementara MB Baru 0.5

MD Sementara MD Baru 0.15

Nilai CF MB Sementara - MD Sementara $0.5-0.15$ 0.35

Penyakit Ulveitis Anterior

Gejala 1 (G001) Mata merah 0.5

$$
0.2
$$

MB Lama

0

MD Lama

0

MB Baru 0.5

Kosong

Kosong

MD Baru

$$
0.2
$$

MB Sementara MB Baru 0.5

MD Sementara MD Baru 0.2

Nilai CF

$$
\begin{gathered}
\text { MB Sementara - MD Sementara } \\
0.5-0.2 \\
0.3
\end{gathered}
$$

Penyakit Skeritis

Gejala 1 (G001) Mata merah 0.5 0.25

MB Lama

Kosong

MD Lama

Kosong 
MB Baru

0.5

MD Baru

MB

0.25

MD

MB Sementara MB Baru

0.5

MD Sementara MD Baru

0.25

Nilai CF

MB Sementara - MD Sementara

$$
0.5-0.25
$$

0.25

Dilihat dari hasil perhitungan yang telah dilakukan secara manual dari 5 gejala yang sudah dipilih oleh user, terdapat 5 penyakit yang memiliki kesesuaian dengan gejala tersebut, nilai CF masingmasing penyakityaitu sebagai berikut :

TABEL 2

Hasil Analisa Perhitungan Nilai CF Penyakit Mata

\begin{tabular}{|l|l|l|}
\multicolumn{3}{|c}{ Hasil Analisa Perhitungan Nilai CF Penyakit Mata } \\
\hline No & Diagnosa & Kepercayaan $(\mathrm{CF})$ \\
\hline 1 & Blefaritis & 0.440565 \\
\hline 2 & Keratitis & 0.4 \\
\hline 3 & Konjungtivitis Sika & 0.35 \\
\hline 4 & Uveitis Anterior & 0.3 \\
\hline 5 & Skleritis & 0.25 \\
\hline
\end{tabular}

\section{Basis Pengetahuan}

Basis pengetahuan sistem pakar penyakit mata didapatkan dari hasil akuisisi pengetahuan. Akuisisi pengetahuan merupakan suatu proses untuk mengumpulkan data-data suatu permasalahan dari seorang pakar dengan menggunakan certainty factor.

TABEL 5.

Basis Pengetahuan Penyakit Mata

\begin{tabular}{|l|l|l|l|l|}
\hline No & Diagnosa & Gejala & MB & MD \\
\hline 1 & $\begin{array}{l}\text { BD01] } \\
\text { Blefaritis } \\
{[\text { G001] Mata merah }}\end{array}$ & 0.9 & 0.15 \\
\hline 2 & $\begin{array}{l}\text { Blefaritis } \\
\text { [D01] } \\
{[\text { D01] }} \\
\text { Blefaritis }\end{array}$ & $\begin{array}{l}\text { [G002] Gatal } \\
\text { berair })\end{array}$ & 0.9 & 0.2 \\
\hline 4 & $\begin{array}{l}\text { Blefaritis } \\
\text { [D004] Eksudat (Ada } \\
\text { sesuatu yang } \\
\text { mengering di mata } \\
\text { dan mengalami } \\
\text { perlekatan pada mata } \\
\text { atas dan bawah) }\end{array}$ & 0.85 & 0.2 \\
\hline 5 & $\begin{array}{l}\text { Blefaritis } \\
\text { [D01] }\end{array}$ & $\begin{array}{l}\text { [G005] Rasa terbakar } \\
\text { pada palpebra }\end{array}$ & 0.8 & 0.1 \\
\hline
\end{tabular}

\begin{tabular}{|c|c|c|c|c|}
\hline No & Diagnosa & Gejala & MB & MD \\
\hline & & (kelopak mata) & & \\
\hline 6 & $\begin{array}{l}\text { [D02] } \\
\text { Skleritis }\end{array}$ & [G001] Mata merah & 0.5 & 0.25 \\
\hline 7 & $\begin{array}{l}{[\mathrm{D} 02]} \\
\text { Skleritis }\end{array}$ & $\begin{array}{l}\text { [G006] Fotofobia } \\
\text { (rasa takut abnormal } \\
\text { pada cahaya) }\end{array}$ & 0.9 & 0.1 \\
\hline 8 & $\begin{array}{l}{[\mathrm{D} 02]} \\
\text { Skleritis }\end{array}$ & $\begin{array}{l}\text { [G007] Penglihatan } \\
\text { menurun }\end{array}$ & 0.8 & 0.2 \\
\hline 9 & $\begin{array}{l}{[\mathrm{D} 03]} \\
\text { Konjungtiviti } \\
\text { s Bakteri }\end{array}$ & [G008] Lakrimasi & 0.9 & 0.1 \\
\hline 10 & $\begin{array}{l}{[\mathrm{D} 03]} \\
\text { Konjungtiviti } \\
\text { s Bakteri }\end{array}$ & $\begin{array}{l}\text { [G009] Terasa benda } \\
\text { asing }\end{array}$ & 0.8 & 0.2 \\
\hline 11 & $\begin{array}{l}{[\mathrm{D} 03]} \\
\text { Konjungtiviti } \\
\text { s Bakteri }\end{array}$ & $\begin{array}{l}\text { [G010] Flikten (ada } 1 \\
\text { tonjolan kecil atau } \\
\text { lebih dan berwarna } \\
\text { merah) }\end{array}$ & 0.9 & 0.1 \\
\hline 12 & $\begin{array}{l}{[\mathrm{D} 04]} \\
\text { Konjungtiviti } \\
\text { s Viral }\end{array}$ & [G008] Lakrimasi & 0.8 & 0.2 \\
\hline 13 & $\begin{array}{l}\text { [D04] } \\
\text { Konjungtiviti } \\
\text { s Viral }\end{array}$ & $\begin{array}{l}\text { [G011] Injeksi } \\
\text { (Pelebaran pada } \\
\text { pembuluh darah pada } \\
\text { mata) }\end{array}$ & 0.8 & 0.2 \\
\hline 14 & $\begin{array}{l}{[\mathrm{D} 04]} \\
\text { Konjungtiviti } \\
\text { s Viral }\end{array}$ & $\begin{array}{l}\text { [G012] Adenopati } \\
\text { preaurikular (Radang } \\
\text { tenggorokan dan } \\
\text { demam) }\end{array}$ & 0.9 & 0.1 \\
\hline 15 & $\begin{array}{l}\text { [D05] } \\
\text { Konjungtiviti } \\
\text { s Sika }\end{array}$ & [G002] Gatal & 0.5 & 0.15 \\
\hline 16 & $\begin{array}{l}\text { [D05] } \\
\text { Konjungtiviti } \\
\text { s Sika }\end{array}$ & [G014] Silau & 0.9 & 0.1 \\
\hline 17 & $\begin{array}{l}{[\mathrm{D} 05]} \\
\text { Konjungtiviti } \\
\text { s Sika }\end{array}$ & $\begin{array}{l}{[\mathrm{G} 015] \text { Seperti }} \\
\text { berpasir }\end{array}$ & 0.9 & 0.1 \\
\hline 18 & $\begin{array}{l}\text { [D05] } \\
\text { Konjungtiviti } \\
\text { s Sika }\end{array}$ & $\begin{array}{l}\text { [G016] Pandangan } \\
\text { kadang kabur }\end{array}$ & 0.5 & 0.1 \\
\hline 19 & $\begin{array}{l}{[\mathrm{D} 06]} \\
\text { Keratitis }\end{array}$ & [G001] Mata merah & 0.6 & 0.2 \\
\hline 20 & $\begin{array}{l}{[\mathrm{D} 06]} \\
\text { Keratitis }\end{array}$ & [G014] Silau & 0.7 & 0.1 \\
\hline 21 & $\begin{array}{l}{[\mathrm{D} 06]} \\
\text { Keratitis }\end{array}$ & $\begin{array}{l}\text { [G017] Terasa ada } \\
\text { yang mengganjal }\end{array}$ & 0.5 & 0.1 \\
\hline 22 & $\begin{array}{l}\text { [D07] } \\
\text { Endoftalmitis }\end{array}$ & [G013] Bengkak & 0.8 & 0.2 \\
\hline
\end{tabular}




\begin{tabular}{|c|c|c|c|c|}
\hline No & Diagnosa & Gejala & MB & MD \\
\hline 23 & $\begin{array}{l}\text { [D07] } \\
\text { Endoftalmitis }\end{array}$ & $\begin{array}{l}\text { [G019] Kelopak mata } \\
\text { berwarna merah }\end{array}$ & 0.7 & 0.1 \\
\hline 24 & $\begin{array}{l}\text { [D07] } \\
\text { Endoftalmitis }\end{array}$ & [G020] Kornea keruh & 0.9 & 0.1 \\
\hline 25 & $\begin{array}{l}\text { [D07] } \\
\text { Endoftalmitis }\end{array}$ & [G021] Pus (nanah) & 0.7 & 0.1 \\
\hline 26 & $\begin{array}{l}\text { [D08] } \\
\text { Uveitis } \\
\text { Anterior }\end{array}$ & [G001] Mata merah & 0.5 & 0.2 \\
\hline 27 & $\begin{array}{l}\text { [D08] } \\
\text { Uveitis } \\
\text { Anterior }\end{array}$ & $\begin{array}{l}{[\mathrm{G} 018] \text { Kekeruhan }} \\
\text { yang berwarna putih }\end{array}$ & 0.7 & 0.1 \\
\hline 28 & $\begin{array}{l}\text { [D08] } \\
\text { Uveitis } \\
\text { Anterior }\end{array}$ & $\begin{array}{l}\text { [G022] Rasa sakit } \\
\text { yang sangat pada mata }\end{array}$ & 0.9 & 0.15 \\
\hline 29 & $\begin{array}{l}\text { [D08] } \\
\text { Uveitis } \\
\text { Anterior }\end{array}$ & $\begin{array}{l}\text { [G023] Sukar melihat } \\
\text { benda yang dekat }\end{array}$ & 0.7 & 0.1 \\
\hline 30 & $\begin{array}{l}\text { [D08] } \\
\text { Uveitis } \\
\text { Anterior }\end{array}$ & $\begin{array}{l}{[\mathrm{G} 024]} \\
\text { Hifema/hipopion }\end{array}$ & 0.7 & 0.1 \\
\hline 31 & $\begin{array}{l}\text { [D08] } \\
\text { Uveitis } \\
\text { Anterior }\end{array}$ & [G025] Benjolan & 0.7 & 0.1 \\
\hline 32 & $\begin{array}{l}\text { [D09] } \\
\text { Ektropion }\end{array}$ & $\begin{array}{l}{[\mathrm{G} 026] \text { Keratitis }} \\
\text { (peradangan pada } \\
\text { kornea) }\end{array}$ & 0.7 & 0.1 \\
\hline 33 & $\begin{array}{l}\text { [D09] } \\
\text { Ektropion }\end{array}$ & $\begin{array}{l}\text { [G027] Lagoftalmus } \\
\text { (kelopak mata tidak } \\
\text { dapat menutup bola } \\
\text { mata) }\end{array}$ & 0.9 & 0.1 \\
\hline 34 & $\begin{array}{l}{[\mathrm{D} 10]} \\
\text { Glaukoma } \\
\text { Akut }\end{array}$ & $\begin{array}{l}\text { [G022] Rasa sakit } \\
\text { yang sangat pada mata }\end{array}$ & 0.9 & 0.1 \\
\hline 35 & $\begin{array}{l}{[\mathrm{D} 10]} \\
\text { Glaukoma } \\
\text { Akut }\end{array}$ & [G028] Mual & 0.5 & 0.1 \\
\hline 36 & $\begin{array}{l}\text { [D10] } \\
\text { Glaukoma } \\
\text { Akut }\end{array}$ & [G029] Muntah & 0.9 & 0.1 \\
\hline 37 & $\begin{array}{l}\text { [D10] } \\
\text { Glaukoma } \\
\text { Akut }\end{array}$ & $\begin{array}{l}\text { [G030] Lingkaran } \\
\text { pelangi }\end{array}$ & 0.6 & 0.2 \\
\hline
\end{tabular}

konteks diagram yang akan menggambarkan aliran data terhadap sistem yang dirancang.

\section{Use Case}

Use Case mendeskripsikan sebuah interaksi antara satu atau lebih aktor dengan sistem informasi yang akan dibuat.

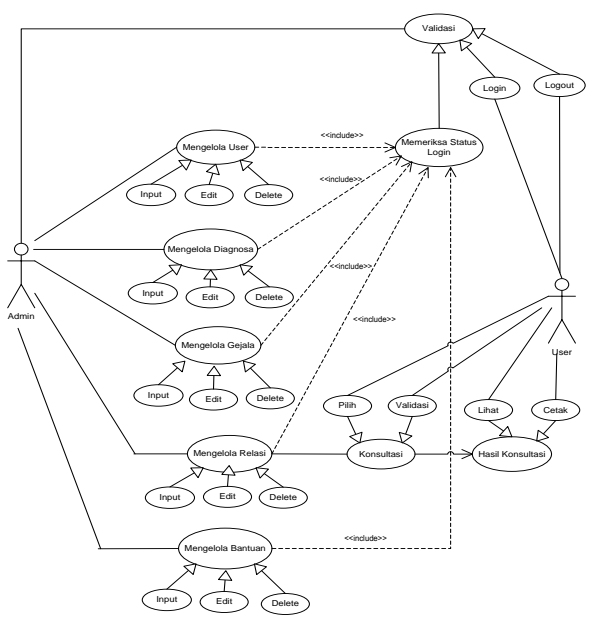

Gambar 3. Use Case DiagramSistem Pakar Diagnosa

2. Class Diagram Penyakit Mata

Class Diagram menggambarkan keadaan (atribut/properti) suatu sistem, sekaligus menawarkan layanan untuk memanipulasi keadaan (metode/fungsi) tersebut. Berikut adalah Class Diagram dari sistem pakar diagnosa penyakit mata:

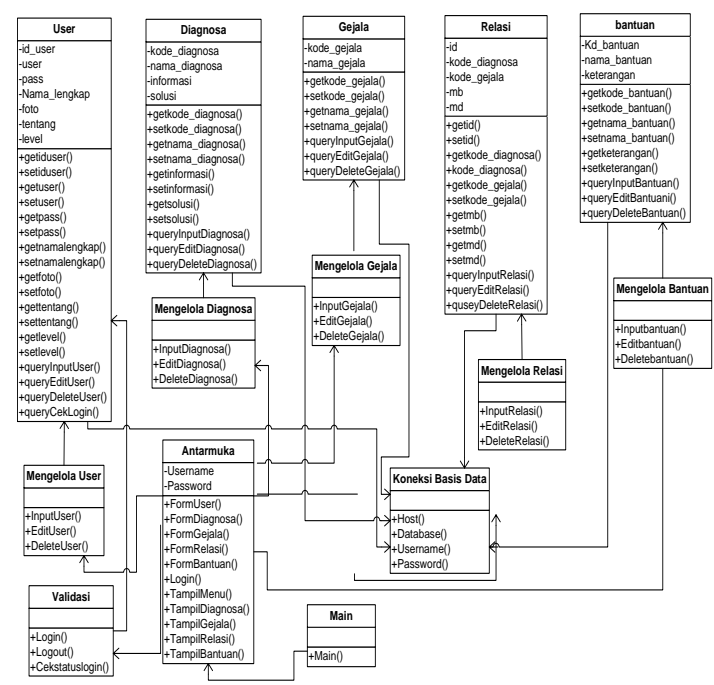

Gambar 4. Class Diagram sistem pakar diagnosa penyakit mata

\section{G. Perancangan Basis Data (Database)}

Merupakan tempat penyimpanan fakta-fakta

\section{E. Perancangan Sistem}

Perancangan sistem menguraikan bagaimana alur proses input maupun out-put dari sistem yang akan dihasilkan. Perancangan sistem ini dapat digambarkan melalui diagram aliran data maupun

yang diketahui dari hasil menjawab pertanyaan, dimana fakta-fakta tersebut bisa di edit kapan saja oleh pakar. Adapun file-file rancangan basis data yang digunakan dalam sistem pakar diagnosa penyakit mata adalah sebagai berikut. 
1) Tabel User

Tabel user digunakan untuk menyimpan data user.

TABEL 6. Tabel User

\begin{tabular}{|l|l|l|l|}
\hline Field & Tipe & Lebar & Keterangan \\
\hline Id_user & Int & 11 & Id_user (primary key) \\
\hline User & Varchar & 16 & User \\
\hline Pass & Varchar & 16 & Pass \\
\hline Nama_lengkap & Varchar & 255 & Nama_lengkap \\
\hline Foto & Varchar & 255 & Foto \\
\hline Tentang & Text & - & Tentang \\
\hline Level & Varchar & 16 & Level \\
\hline
\end{tabular}

2) Tabel Gejala

Tabel gejala digunakan untuk menyimpan data gejala-gejala penyakit mata.

TABEL 7. Tabel Gejala

\begin{tabular}{|l|l|l|c|l|}
\hline No & \multicolumn{1}{|c|}{ Nama Field } & Type Field & Panjang & \multicolumn{1}{|c|}{ Keterangan } \\
\hline 1 & $\underline{\text { kd gejala }}$ & Varchar & 8 & Kode gejala (primary key) \\
\hline 2 & Gejala & Varchar & 256 & Nama gejala \\
\hline 3 & keterangan & Varchar & 256 & Keterangan \\
\hline
\end{tabular}

3) Tabel Diagnosa (Penyakit)

Tabel diagnosa (penyakit) digunakan untuk menyimpan data-data penyakit mata.

TABEL 8. Tabel Penyakit

\begin{tabular}{|l|l|l|c|l|}
\hline No & Nama Field & Type Field & Panjang & \multicolumn{1}{|c|}{ Keterangan } \\
\hline 1 & kd diagnosa & Varchar & 1 & Kode penyakit (primary key) \\
\hline 2 & nama_diagnosa & Varchar & 255 & Nama penyakit \\
\hline 3 & Informasi & Text & - & Definisi penyakit \\
\hline 4 & Solusi & Text & - & Solusi penyakit \\
\hline
\end{tabular}

4) Tabel Relasi

Tabel relasi digunakan untuk menginputkandata relasi antara gejala dan penyakit. Pengesetan relasi ini digunakan untuk membuat rule berdasarkan pada basis pengetahuan.

TABEL 9. Tabel Relasi

\begin{tabular}{|l|l|l|c|l|}
\hline No & Nama Field & Type Field & Panjang & \multicolumn{1}{|c|}{ Keterangan } \\
\hline 1 & $\underline{\text { id_rule }}$ & Int & 11 & Kode rule (primary key) \\
\hline 2 & kd_diagnosa & Varchar & 16 & Kode penyakit \\
\hline 3 & kd_gejala & Varchar & 16 & Kode gejala \\
\hline 4 & Mb & Double & 1 & Nilai mb \\
\hline 5 & Md & Double & & Nilai md \\
\hline
\end{tabular}

5) Tabel Bantuan

Tabel analisa bantuan digunakan untuk membantu pasien dari gejala penyakit.
TABEL 10 Tabel Bantuan

\begin{tabular}{|l|l|l|c|l|}
\hline No & Nama Field & Type Field & Panjang & \multicolumn{1}{|c|}{ Keterangan } \\
\hline 1 & kode bantuan & Varchar & 20 & Kode bantuan \\
\hline 2 & nama_bantuan & Varchar & 255 & Nama bantuan(primary key) \\
\hline 3 & Keterangan & Text & - & Keterangan \\
\hline
\end{tabular}

\section{H. Implementasi Sistem}

Tahap implementasi sistem (system implementation) merupakan tahapan penerapan sistem supaya siap untuk dioperasikan. Tahap ini termasuk juga kegiatan menulis kode program jika tidak digunakan paket perangkat lunak aplikasi. Tujuan implementasi sistem adalah untuk menjelaskan manual modul kepada user yang akan menggunakan sistem, sehingga user dapat merespon apa yang ditampilkan oleh sistem.

1. Tampilan Form Login

Adapun Tampilan halaman login dari Aplikasi Pendiagnosa Penyakit Mata Dengan Menggunakan Metode Certainty Factor pada RSUD H. Abdul Manan Simatupang Kisaran :

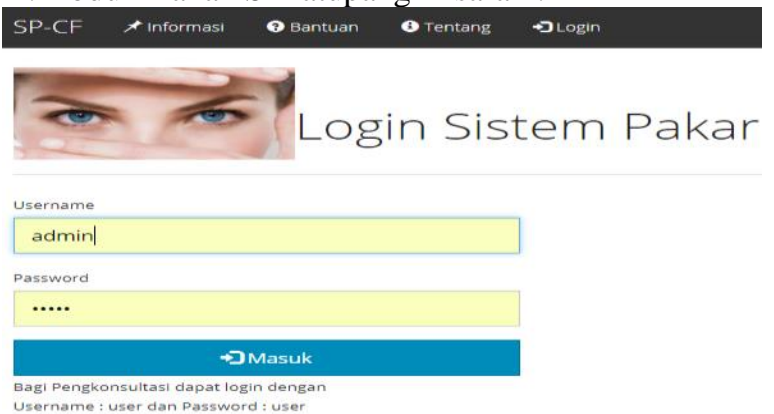

Pade RSUD HAMs $k$

Gambar 5. Tampilan Halaman Login

2. Tampilan Halaman Utama Admin

Halaman utama admin sistem pakar diagnosa penyakit mata merupakan tampilan awal setelah admin melakukan login. Halaman utama terdiri dari beberapa submenu yaitu menu diagnosa, gejala, relasi, konsultasi, bantuan, profil, password dan logout. Adapun tampilan halaman utama admin sistem pakar diagnosa penyakit mata menggunakan metode certainty factor pada RSUD HAMS Kisaran yaitu

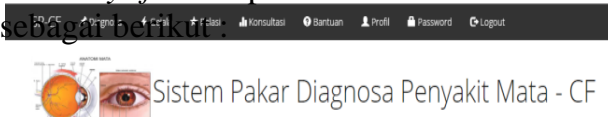

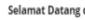


3. Tampilan Halaman Diagnosa

Adapun Tampilan halaman diagnosa dari Aplikasi Pendiagnosa Penyakit Mata Dengan Menggunakan Metode Certainly Factor pada RSUD H. Abdul Manan Simatupang Kisaran :

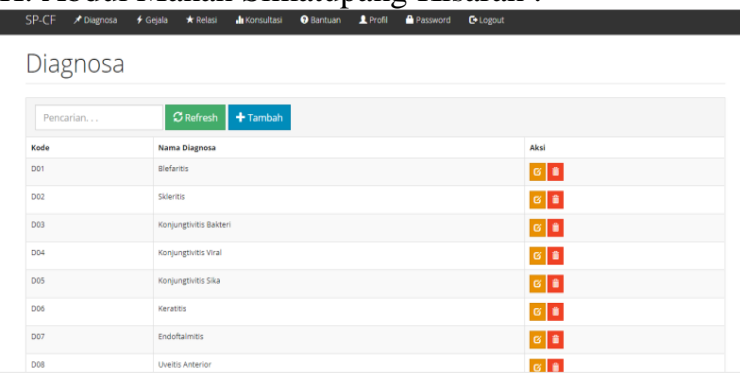

Gambar 7. Tampilan Halaman Diagnosa

4. Tampilan Halaman Gejala

Adapun Tampilan halaman gejala dari

Aplikasi Pendiagnosa Penyakit Mata Dengan Menggunakan Metode Certainly Factor pada RSUD H. Abdul Manan Simatupang Kisaran :

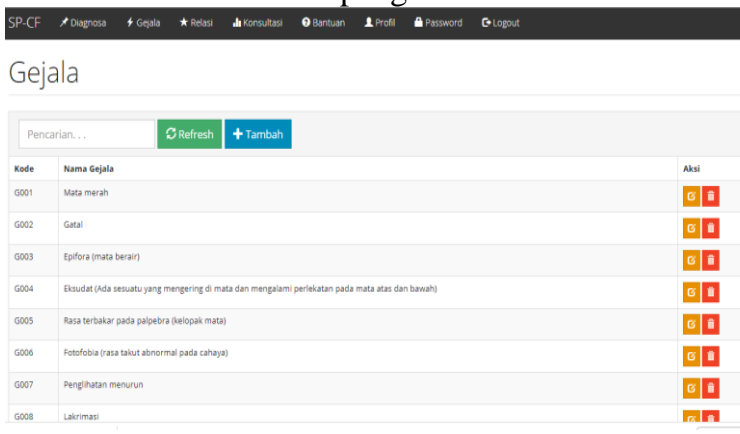

Gambar 8. Tampilan Halaman Gejala

5. Tampilan Halaman Konsultasi

Adapun Tampilan halaman konsultasi dari Aplikasi Pendiagnosa Penyakit Mata Dengan Menggunakan Metode Certainty Factor pada RSUD H. Abdul Manan Simatupang Kisaran :

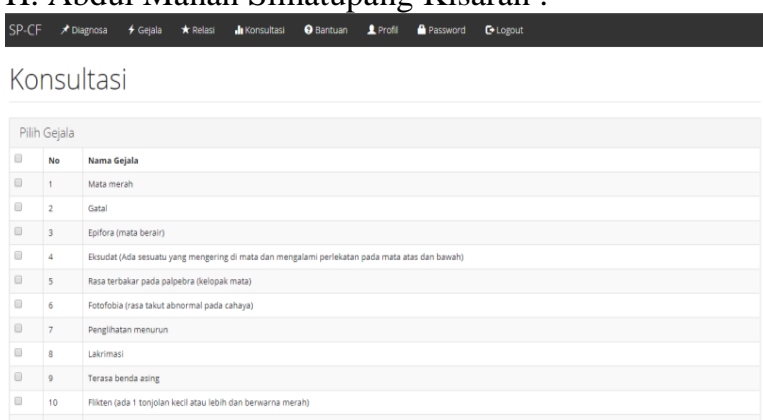

Gambar 9. Tampilan Halaman Konsultasi

\section{Tampilan Halaman Konsultasi User}

Untuk mengetahui hasil pengujian output dari sistem pakar ini, sistem akan memberikan sejumlah pertanyaan berupa gejala-gejala mata, dimana user bisa memilih gejala-gejala yang dialaminya dengan melakukan cek list dari daftar pertanyaan yang telah disediakan oleh sistem. Selanjutnya sistem akan memproses jawaban dari user dan akan menampilkan hasil konsultasi yaitu jenis penyakit mata, nilai certainty factor, serta pengobatan dari penyakit tersebut. Gejala yang terdapat pada metode diagnosa wawancara memiliki deskripsi yang umum, sehingga user perlu mencermati tiap pertanyaan dengan baik.

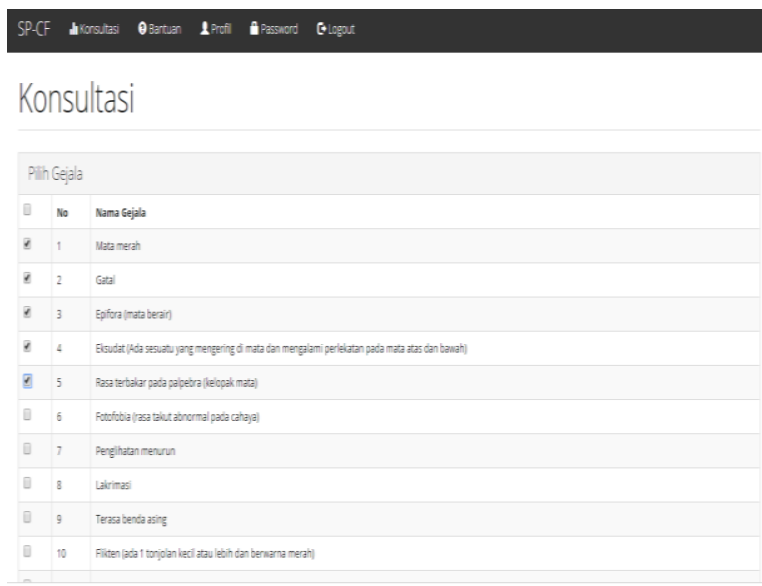

Gambar 10. Tampilan Halaman Konsultasi User

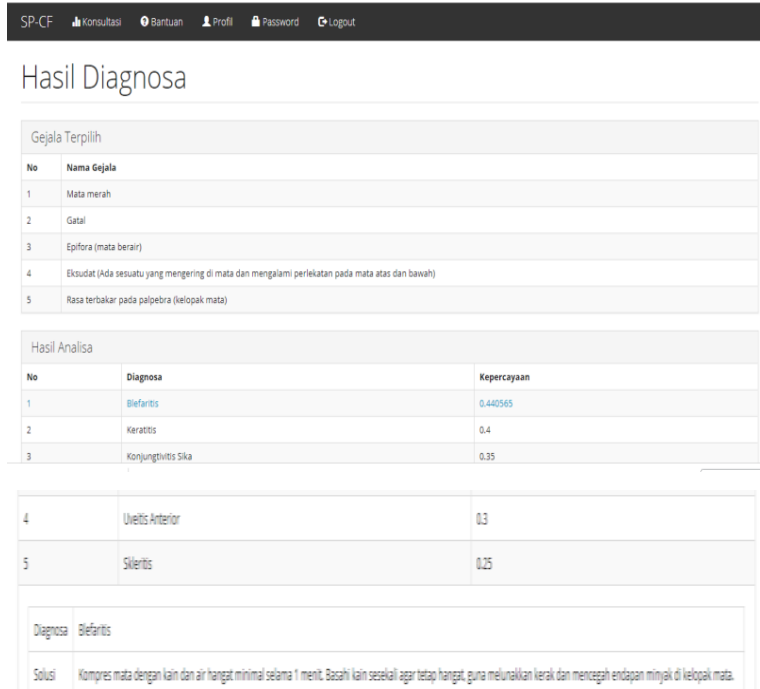

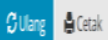

Gambar 11. Tampilan Halaman Hasil Konsultasi User

\section{A. Kesimpulan}

\section{KESIMPULAN DAN SARAN}

Berdasarkan hasil pembahasan teori pada perancangan sistem pakar diagnosa penyakit Mata dapat disimpulkan sebagai berikut :

1. Sistem pakar dapat mendiagnosa penyakit Mata untuk dapat diketahui penyakit apa yang dialami oleh pasien.

2. Sistem pakar diagnosa penyakit Mata mampu memberikan solusi untuk penanganan penyakit yang telah di diagnosa.

3. Sistem yang berbasis web dapat di akses oleh semua pasien penyakit Mata karena sistem yang dijalankan pada aplikasi web. 
4. Metode Certainty Factor mampu mendeteksi jenis penyakit dan dapat memberikan informasi pengobatan penyakit.

\section{B. Saran}

Adapun saran-saran dari penulis untuk penggunaan website sistem pakar diagnosa penyakit Mata dapat diperhatikan sebagai berikut :

1. Dalam menggunakan website sistem pakar diagnosa penyakit Mata agar dapat diakses dengan cepat disarankan menggunakan koneksi internet yang memadai.

2. Bagi admin dapat memeriksa penggunapengguna yang melakukan registrasi yang tidak valid dan disarankan dapat menghapusnya dari database agar tidak terjadi spam.

3. Bagi admin dalam pemeliharaan database agar selalu memperhatikan ruang penyimpanan. Penggunaan ruang penyimpanan sangat disarankan hanya untuk data yang valid guna menghemat ruang penyimpanan yang mempercepat proses sistem.

\section{DAFTAR PUSTAKA}

[1] Dzulkifli Fitriana et. All. 2016. "Sistem Pendukung Keputusan Pengadaan Raw Material Pembuatan Mie Instan Menggunakan Metode Analitycal Hierarchy Process (AHP) Studi Kasus PT. Indofood CBP Sukses Makmur", E-Journal Teknik Informatika, Vol. 9 No. 1, 1-5.

[2] Edi Iskandar. 2007. “ Sistem Pakar Untuk Diagnosa Penyakit ISPA Menggunakan Metode Faktor Kepastian", Jurnal Ilmiah STMIK GI MDP, Vol. 3, No.1, 9-16.

[3] Edi Wijaya. 2013. "Analisis Penggunaan Algoritma Breadth First Search Dalam Konsep Artificial Intellegencia", Jurnal TIME , Vol. II No 2, 18-26.

[4] Eka Wida Fridayanthie dan Tias Mahdiati. 2016.'Rancang Bangun Sistem Informasi Permintaan ATK Berbasis Internet" Jurnal Khatulistiwa Informatika, Vol. IV, No. 2, 126138.

[5] Eli Rosmita Ritonga dan Muhammad Dedi Irawan. 2017. "Sistem Pakar Diagnosa Penyakit Paru-Paru Pada Anak Dengan Metode Dempster-Shafer", Vol. 2, No. 1, 39-47.

[6] Gellysa Urva dan Helmi Fauzi Siregar. 2015. "Pemodelan UML E-Marketing Minyak Goreng", Jurnal Teknologi dan Sistem Informasi, Vol. I, No. 2, 92-101.

[7] Reppy Reisa et.All. 2013. "Sistem Pakar Untuk Diagnosis Penyakit Mata", Jurnal Sistem Informasi, Vol 2, No 2, 30-39. 